\title{
Implementasi Model View Presenter dan \\ Object Relational Mapping NHibernate pada Aplikasi eStop Card berbasis Web (Studi Kasus: PT. XYZ Jakarta)
}

\author{
Alessandro Christoforus B ${ }^{1}$ \\ andobaramuli@gmail.com
}

\author{
Adi Nugroho ${ }^{2}$ \\ adi.nugroho@staff.uksw.edu
}

\author{
Angela Atik Setiyanti ${ }^{3}$ \\ setya_angela@yahoo.co.id
}

\begin{abstract}
The development of technology has shown significant progress, especially in application architecture design pattern. Model View Presenter (MVP) pattern is one of the most important pattern used for extracting business logic outside of User Interface (UI) elements and by that enabling unit test without the need testing tools, and specifically geared towards for page event model in ASP.NET. Together with MVP, Object Relational Mapping (ORM) NHibernate is implemented to build a web base application. ORM is a technique to map an object to a database. It can be concluded that the implementation MVP and ORM to build a web base application resulting a well-performed and easily maintained application as well as it effectiveness when performing unit test, and also a clear separation layer between model, view, presenter.
\end{abstract}

Keywords: Model View Presenter (MVP), Object Relational Mapping (ORM).

\section{PENDAHULUAN}

Dalam pengembangan perangkat lunak aplikasi, design pattern merupakan solusi yang dibuat untuk menyelesaikan masalah yang bersifat teknis dengan menyediakan suatu arsitektur aplikasi. Design pattern tidak hanya berupa suatu pola desain yang secara langsung diterjemahkan ke dalam barisan kode program, tetapi merupakan suatu deskripsi atau model untuk menyelesaikan masalah yang dapat digunakan pada situasi-situasi berbeda. Hal ini secara khusus menunjukkan hubungan antara kelas dan obyek dalam arsitektur aplikasi.

Arsitektur suatu aplikasi merupakan desain standar yang digunakan untuk mengatasi isu-isu dalam rekayasa perangkat lunak, seperti keterbatasan performa perangkat keras komputer, memperkecil resiko bisnis, dan isu yang lainnya. Suatu arsitektur aplikasi dapat

\footnotetext{
${ }_{1}^{1}$ MahasiswaTeknik Informatika, Fakultas Teknologi Informasi, Universitas Kristen Duta Wacana, Yogyakarta

${ }^{2}$ Staf pengajar, Fakultas Teknologi Informasi, Universitas Kristen Duta Wacana, Yogyakarta

${ }^{3}$ Staf pengajar, Fakultas Teknologi Informasi, Universitas Kristen Duta Wacana, Yogyakarta
} 
dipisahkan ke dalam beberapa inti layer atau komponen aplikasi. Dalam membangun suatu arsitektur aplikasi, ada penerapan suatu teknik pemrograman. Hal ini memberikan kesempatan kepada para pengembang aplikasi untuk mengembangkan aplikasi dengan performa terbaik.

Banyak teknik pemrograman yang dapat digunakan dalam mengembangkan aplikasi. Salah satu teknik yang digunakan untuk mengembangkan aplikasi adalah Model View Presenter (MVP). Teknik MVP diimplementasikan dengan tujuan untuk memisahkan tanggung jawab dari masing-masing bagian yaitu Data Representation, User Interface (UI), dan Business Logic aplikasi dalam tiga bagian besar yaitu model, view, dan presenter. Dalam melakukan implementasi Model View Presenter (MVP) di dalamnya ditambahkan suatu teknik Object Relational Mapping (ORM). Teknik ORM digunakan untuk memetakan setiap atribut dari suatu obyek ke dalam tabel pada basis data. Penelitian ini ditujukan untuk melakukan implementasi teknik pemrograman Model View Presenter (MVP) serta teknik Object Relational Mapping (ORM) NHibernate dalam membuat aplikasi eStop Card berbasis web pada modul Master Management di PT. XYZ.

\section{KAJIAN PUSTAKA}

Setelah bertahun-tahun melakukan perawatan ribuan baris kode ASP Spaghetti, pada akhirnya Microsoft mengeluarkan suatu platform untuk pengembangan web yaitu ASP.NET. Secara langsung, ASP.NET memberikan pemisahan dasar antara presentation layer dan business logic layer dengan memperkenalkan code behind page. Meskipun telah diperkenalkan dengan baik dan sempurna untuk suatu aplikasi, code behind page masih memiliki sejumlah kekurangan dalam aspek sebagai mediator antar layer yang menyebabkan banyaknya tanggung jawab yang harus dikerjakan, sulit untuk menggunakan presentation logic antar code behind page tanpa mendaftarkan helper/utility, sulit melakukan unit testing pada code behind page [1].

Pada jurnal dengan judul Model View Presenter design pattern menjelaskan bahwa MVP adalah suatu tipe User Interface (UI) design pattern yang mengijinkan pemisahan antarmuka pengguna dan lapisan akses data [2]. Salah satu keuntungan dengan menggunakan teknik MVP adalah mudah melakukan pengujian action sederhana tanpa menggunakan tool khusus pengujian. Semua logical process diletakkan dalam presenter dan interaksi antara view dan presenter hanya melalui interface class, sehingga setiap obyek tiruan dapat digunakan untuk pengujian selama itu mengimplementasikan view interface [3].

NHibernate in Action, menjelaskan tentang model pemrograman dimana suatu aplikasi dapat dilakukan penambahan perancangan dan penerapan suatu kelas persistent 
untuk bagaimana kelas tersebut mengidentifikasi business object (entitas) dan memetakannya ke dalam basis data menggunakan teknik ORM dan pendekatan XML [4]. Berdasarkan beberapa teori dan konsep yang dikemukakan oleh beberapa orang tersebut, maka peneliti mencoba melakukan suatu implementasi MVP dan ORM dalam membuat aplikasi eStop Card berbasis web pada modul Master Management.

\subsection{Model View Presenter (MVP)}

MVP adalah teknik pemrograman yang secara khusus mengarah ke page event model seperti ASP.NET [1]. Arsitektur MVP terlihat pada Gambar 1.

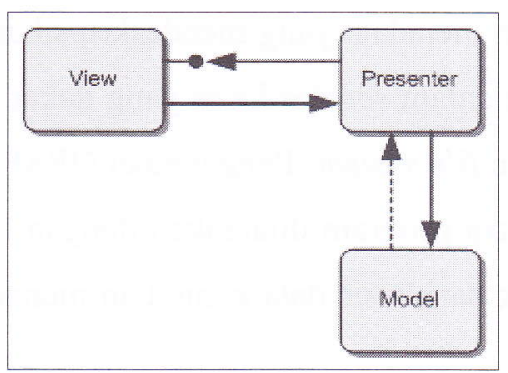

Gambar 1 Arsitektur MVP[5]

Model bisa dikatakan sebagai domain level object, dan dikenal sebagai business object. Tugas utama model adalah menjaga data dan fungsi/method pada aplikasi untuk secara konsisten dapat diakses. View adalah bagian yang bertanggungjawab terhadap representasi antarmuka dengan pengguna. Presenter adalah bagian yang bertanggungjawab untuk memanipulasi model sebagai respon terhadap input dari pengguna. Proses interaksi pengguna akhir aplikasi yang dibangun dengan menggunakan arsitektur MVP, dapat dilihat pada Gambar 2.

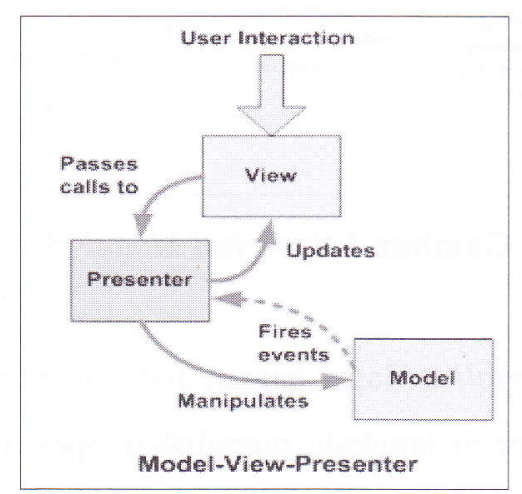

Gambar 2 Alur kerja MVP [6] 
Pada Gambar 2, dimulai dengan pengguna melakukan permintaan dan interaksi langsung dengan view dan event ini diambil alih oleh beberapa life-cycle event pada view/page kemudian presenter melakukan get atau set data dari bussines logic. Presenter mengisi view dengan memberikan properties dan tampilan yang diberikan merupakan respon yang dikirimkan kepada pengguna. Pemisahan fokus layering direalisasikan pada IView Interface. Oleh sebab itu presenter dapat mengetahui apa yang menjadi tugasnya dan bertindak sesuai dengan fungsinya.

\subsection{Object Relational Mapping (ORM) NHibernate}

ORM adalah teknik otomasi dan transparansi dari object persistence ke dalam tabel pada basis data, menggunakan metadata yang mendeskripsikan pemetaan antara obyek dan basis data [7]. ORM berperan dalam service layer yang dekat dengan sumber data, baik itu dari database, webservice, dan file system. Penggunaan ORM dibuat untuk melakukan aksi terkait komunikasi obyek ketika program dijalankan dengan basis data seperti menyimpan obyek, mengambil data obyek dari basis data kemudian menampilkannya, menghapus, dan mengubah obyek.

\section{PERANCANGAN SISTEM}

\subsection{Motede Pengembangan Sistem}

Dalam penelitian ini, pengembangan aplikasi dilakukan menggunakan metode waterfall. Pada waterfall, pengembangan aplikasi dilakukan dengan fasenya terorganisasi dalam linear order sehingga dapat menjamin pengembangan aplikasi dengan adanya dokumentasi dan desain untuk memastikan kualitas, tahan uji, dan perawatan dari aplikasi yang dikembangkan.

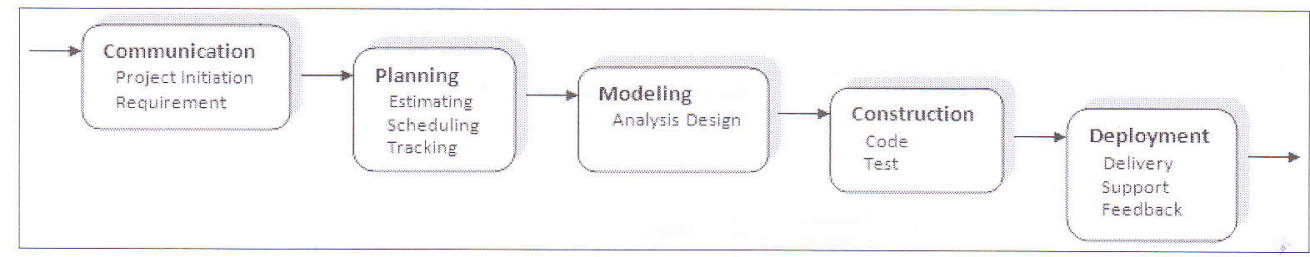

Gambar 3 Waterfall Model [8]

Suatu pendekatan waterfall terdapat bagian atau sarana yang di dalamnya dilakukan secara berurut atau langkah demi langkah, menuliskan spesifikasi suatu sistem kemudian adanya suatu persetujuan, serta pengguna mempunyai batasan tertentu dalam suatu sistem. Dalam hal ini dimaksudkan pendekatan waterfall dilakukan secara bertahap dan berskala, kalau sudah berada pada tahap berikutnya, berarti tidak bisa kembali ke tahap sebelumnya. 


\subsection{Analisis Kebutuhan}

Analisis kebutuhan dalam perancangan aplikasi eStop Card merupakan penyesuaian dari dokumentasi aplikasi di PT. XYZ, yang mendeskripsikan tentang proses bisnis dari Stop Card, dokumen yang digunakan, dan aturan bisnis sistem. Proses Bisnis dari Stop Card di PT. XYZ adalah serangkaian aktifitas yang mencatat dan mengevaluasi tingkat kewaspadaan setiap karyawan yang bekerja di fasilitas perusahaan. Pencatatan tingkat kewaspadaan karyawan dilakukan dengan menuliskan aktifitas yang terlihat yaitu berupa kesalahan dari seorang karyawan dan dicatatkan pada satu manual stop card. Terdapat 3 (tiga) bagian besar dalam proses Stop Card yaitu Manual Stop, Master Management, dan Report. Dan dalam pengembangan aplikasi eStop Card berbasis web, analisis kebutuhan dibatasi pada bagian Master Management.

Dokumen yang digunakan sebelum menggunakan sistem terintegrasi adalah dokumen stop card serta laporan statistik dari Departemen Health Safety Environmental dan Departemen Operation. Dokumen stop card adalah dokumen formal yang mencatat dan mengevaluasi tingkat kewaspadaan karyawan dalam bekerja di fasilitas perusahaan. Sedangkan laporan statistik yang digunakan dalam bentuk Microsoft Office Excel berisi informasi berupa jumlah manual stop card yang dilaporkan, tingkat kewaspadaan karyawan perusahaan, aktifitas yang dilakukan karyawan dari suatu departemen.

Aturan bisnis sistem dari aplikasi eStop Card dibatasi pada modul Master Management. Master Management merupakan modul dengan level tertinggi dalam aplikasi yang akan dikembangkan. Pada modul Master Management, seorang pengguna yang terautentikasi oleh sistem dapat melakukan tambah, lihat, ubah, dan hapus data pada sembilan submodul dari modul Master Management. Dalam modul Master Management pengguna dapat mengatur submodul:

- Departement Data: departemen target observasi dan departemen observer.

- Location Data: lokasi target observasi.

- Workgroup Data: kelompok target observasi.

- Company Data: perusahaan observer yang mana tidak memiliki fungsional ID.

- Category and Sub Category Data: kategori dan sub kategori dari halaman 1 - STOP Category dan halaman 2 - STOP root cause in STOP Card Page.

- Status: status observasi.

- Intervention level: level

- Activity Observed: aktifitas observasi 


\subsection{Perancangan}

Tahap perancangan dilakukan untuk memberikan gambaran awal yang jelas tentang apa yang harus dikerjakan dalam tahap pembuatan aplikasi. Rancangan yang dibuat juga dapat dipakai sebagai dokumentasi aplikasi.

\subsubsection{Rancangan Tampilan Aplikasi}

Gambar 4 adalah bentuk dasar dari tampilan aplikasi. Aplikasi berbasis web dengan tampilan dasar yang terdiri dari header, menu drop down, dan content.

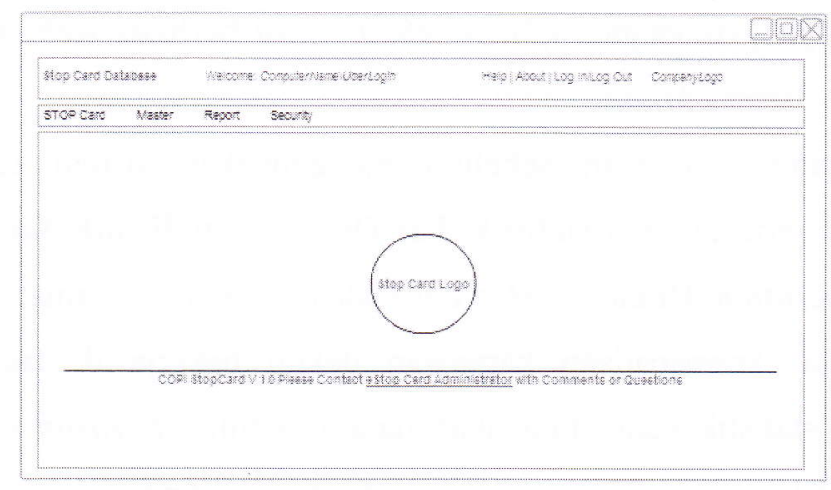

Gambar 4 Rancangan Tampilan Aplikasi

\subsubsection{Rancan gn Dia gam Use Case}

Use Case ini didesain secara keseluruhan, dengan menggambarkan aktor yang terlibat dalam satu atau lebih proses. Semua proses dalam sistem membutuhkan campur tangan aktor yang terautentikasi oleh sistem.

Rancangan diagram Use Case pada modul Master Management digunakan untuk menggambarkan fungsi-fungsi mengelola data oleh pengguna dalam submodul: Departement, Location, Workgroup, Company, Category, Sub Category, Status, Intervention Level, Activity Observed, terlihat pada Gambar 5.

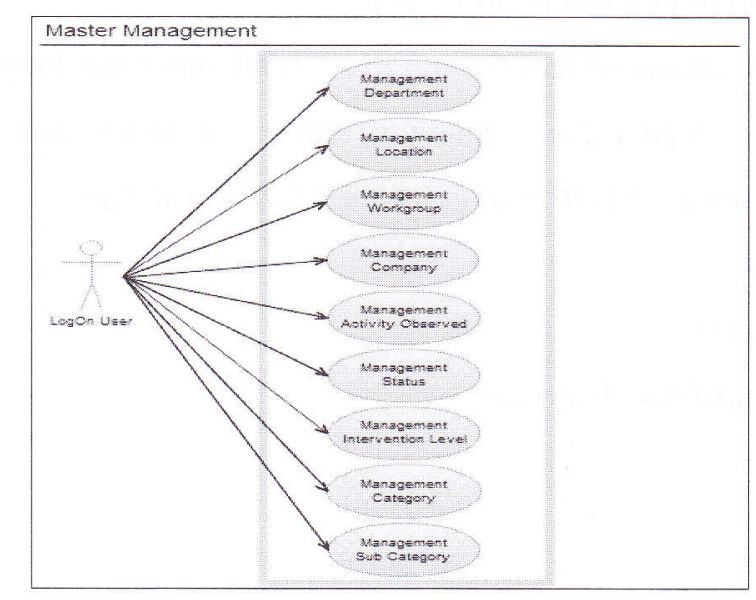

Gambar 5 Diagram Use Case Master Management 


\subsubsection{Rancangan Diagram Activity}

Rancangan diagram activity dari modul Master Management hanya terbagi dalam 4 aktifitas yaitu tambah, lihat, edit, dan hapus data untuk semua submodul: Department, Location, Workgroup, Company, Activity Observed, Status, Intervention Level, Category, Sub Category. Oleh karena itu, activity untuk setiap submodul terlihat pada Gambar 6, Gambar 7, Gambar 8, dan Gambar 9.

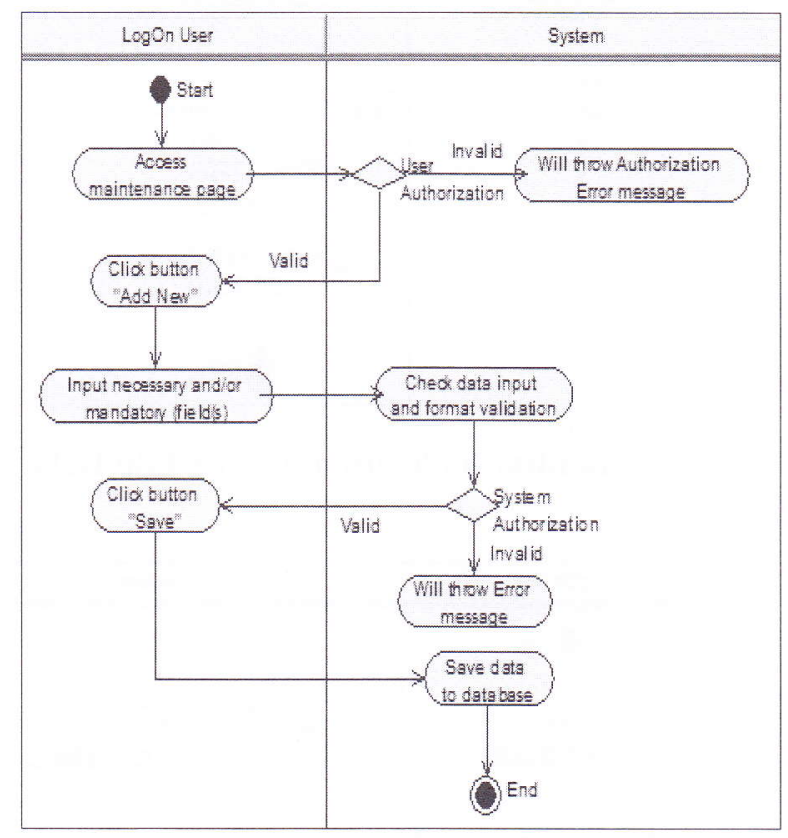

Gambar 6 Diagram Activity Tambah Data

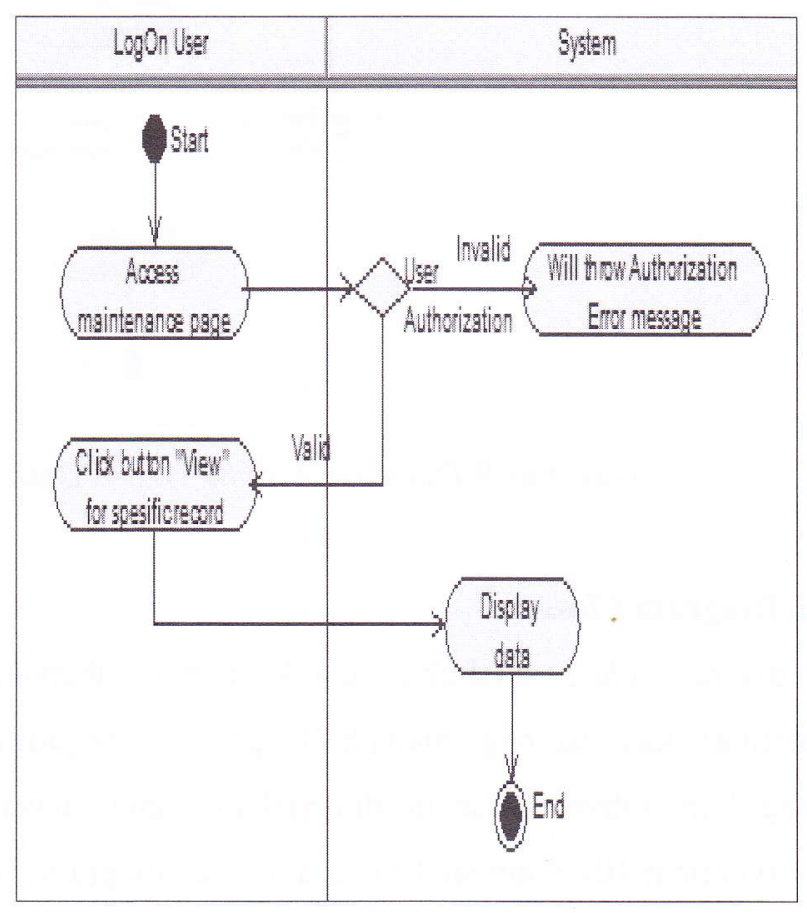

Gambar 7 Diagram Activity Lihat Data 


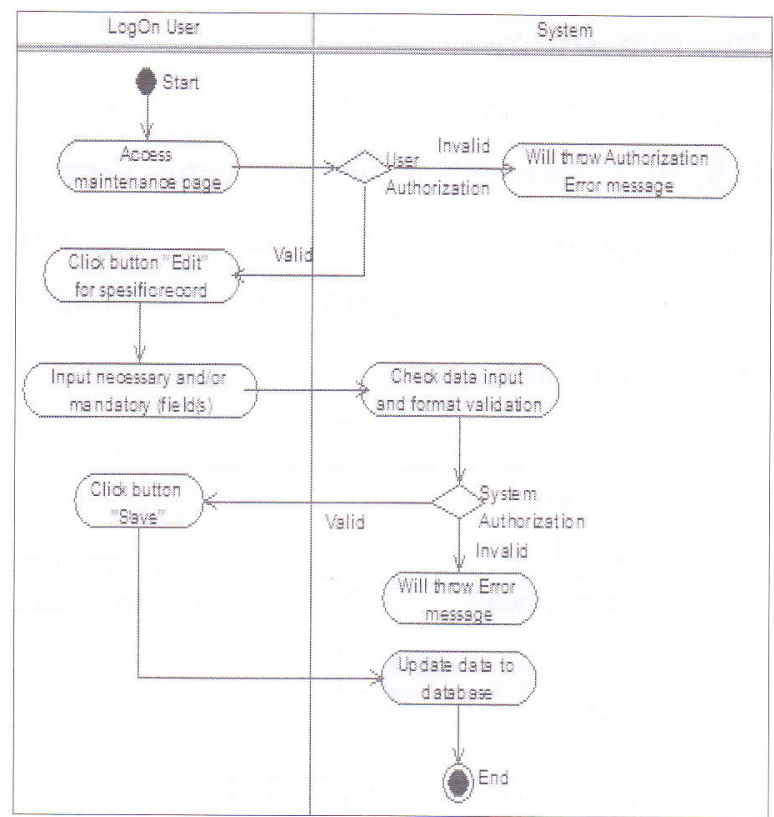

Gambar 8 Diagram Activity Edit Data

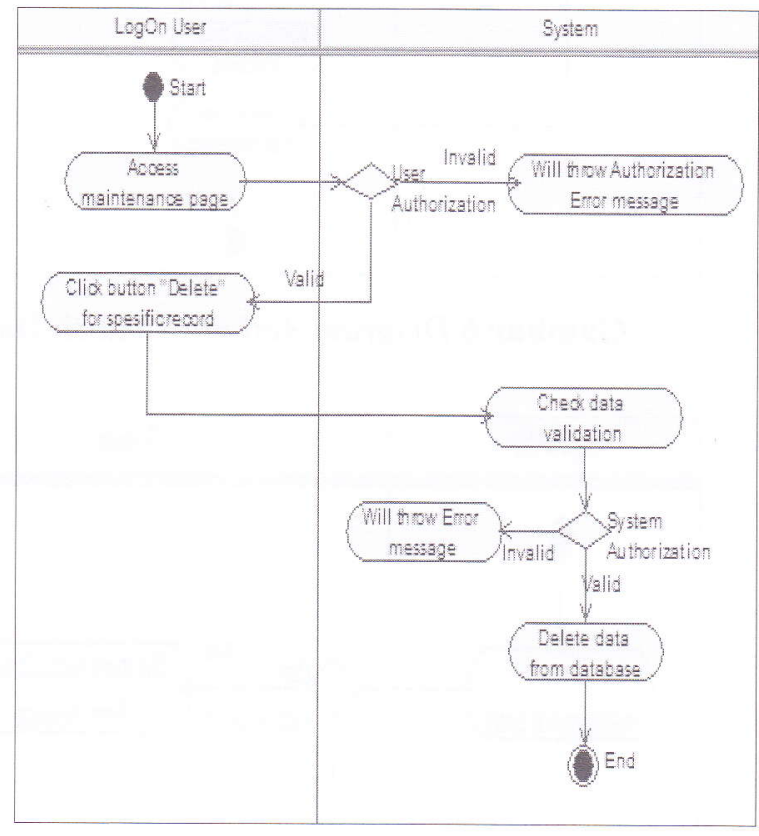

Gambar 9 Diagram Activity Hapus Data

\subsubsection{Rancangan Diagram Class}

Rancangan diagram class dilakukan untuk menggambarkan obyek-obyek yang menjadi bagian dalam aplikasi dan bagaimana hubungan yang terjadi antar obyek yang satu dengan obyek yang lain. Obyek tersebut dinyatakan menggunakan pendekatan object relational mapping (Gambar 10). Gambar 10 menunjukkan diagram class eStop Card. 


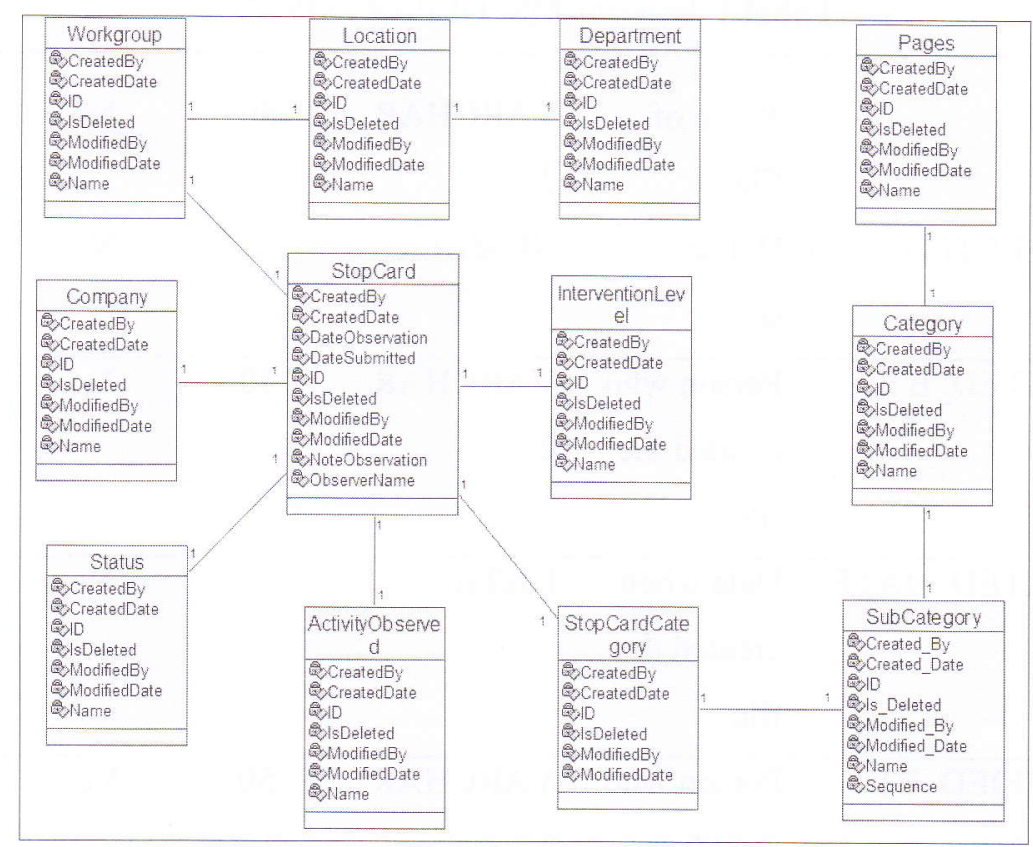

Gambar 10 Diagram Class eStop Card

Diagram pada Gambar 10 menunjukkan representasi dari aplikasi yang akan dibuat. Dan dalam rancangan basis data aplikasi eStop Card berbasis web terdapat tabel-tabel yang digunakan untuk menyimpan data dari modul Master Management. Tabel-tabel tersebut adalah MS_DEPARTMENT, MS_LOCATION, MS_WORKGROUP, MS_PAGES, MS_CATEGORY, MS_SUB_CATEGORY, TRX_STOP_CARD_CATEGORY, TRX_STOP_CARD, MS_ACTIVITY_OBSERVED, MS_STATUS, MS_COMPANY, MS_INTERVENTION_LEVEL. Tabel 1 merupakan salah satu tabel pada basis data, yaitu tabel MS_DEPARTMENT.

Tabel 1 MS_DEPARTMENT

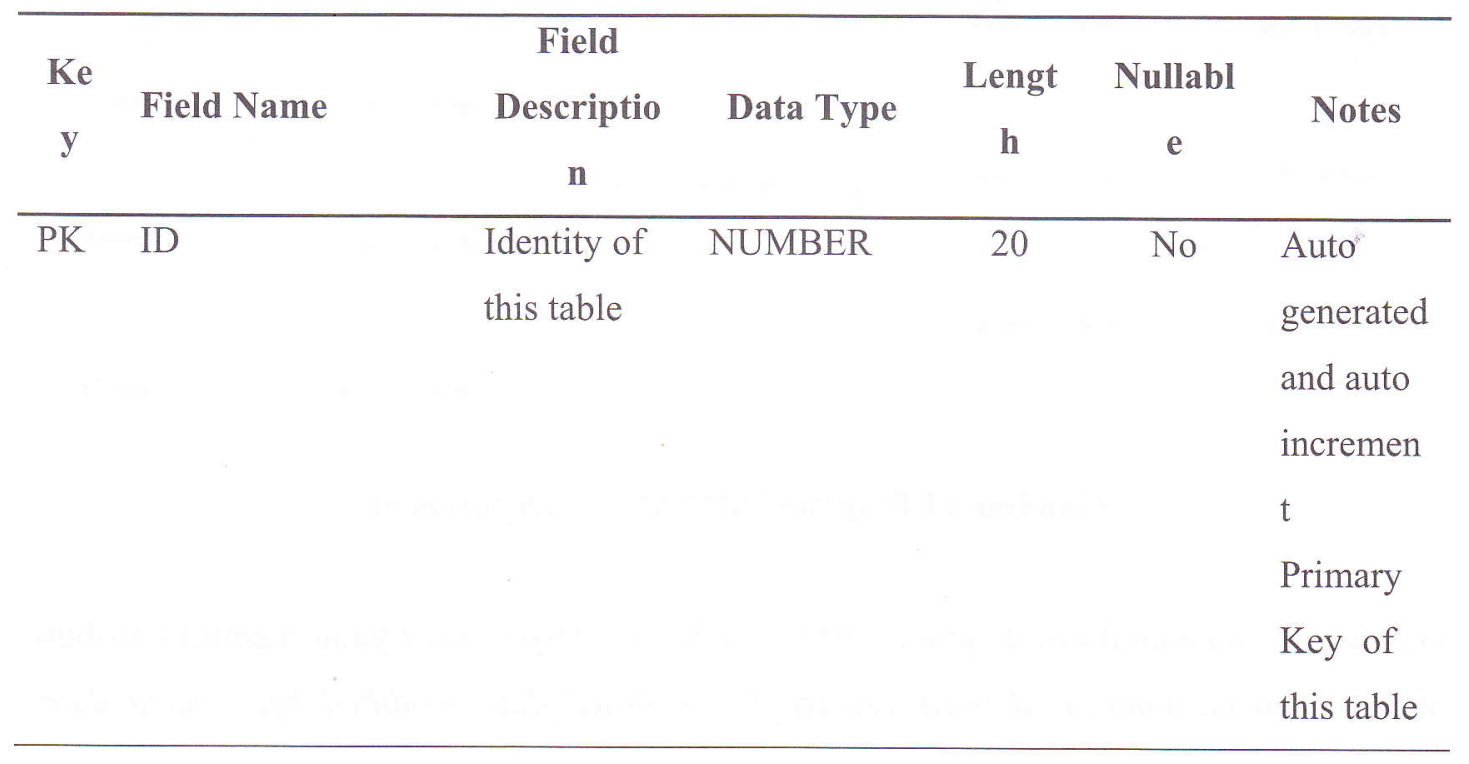


Tabel 1 (lanjutan) MS_DEPARTMENT

\begin{tabular}{|c|c|c|c|c|}
\hline NAME & $\begin{array}{l}\text { Name of } \\
\text { file }\end{array}$ & $\begin{array}{l}\text { VARCHAR } \\
2\end{array}$ & 50 & No \\
\hline IS_DELETED & $\begin{array}{l}\text { Delete } \\
\text { status }\end{array}$ & NUMBER & 1 & No \\
\hline CREATED_BY & $\begin{array}{l}\text { Person who } \\
\text { created the } \\
\text { file }\end{array}$ & $\begin{array}{l}\text { VARCHAR } \\
2\end{array}$ & 50 & No \\
\hline CREATED_DATE & $\begin{array}{l}\text { Date when } \\
\text { created the } \\
\text { file }\end{array}$ & DATE & & No \\
\hline MODIFIED_BY & $\begin{array}{l}\text { Person who } \\
\text { modified } \\
\text { the file }\end{array}$ & $\begin{array}{l}\text { VARCHAR } \\
2\end{array}$ & 50 & Yes \\
\hline $\begin{array}{l}\text { MODIFIED_DAT } \\
\mathrm{E}\end{array}$ & $\begin{array}{l}\text { Date when } \\
\text { modified } \\
\text { the file }\end{array}$ & DATE & & Yes \\
\hline
\end{tabular}

\subsubsection{Rancangan Diagram Object Relational Mapping (ORM)}

Rancangan diagram ORM modul Master Management dilakukan untuk menggambarkan atribut-atribut suatu obyek. Rancangan diagram ORM ini dapat dilihat pada salah satu submodul Master Management yaitu Master Department.

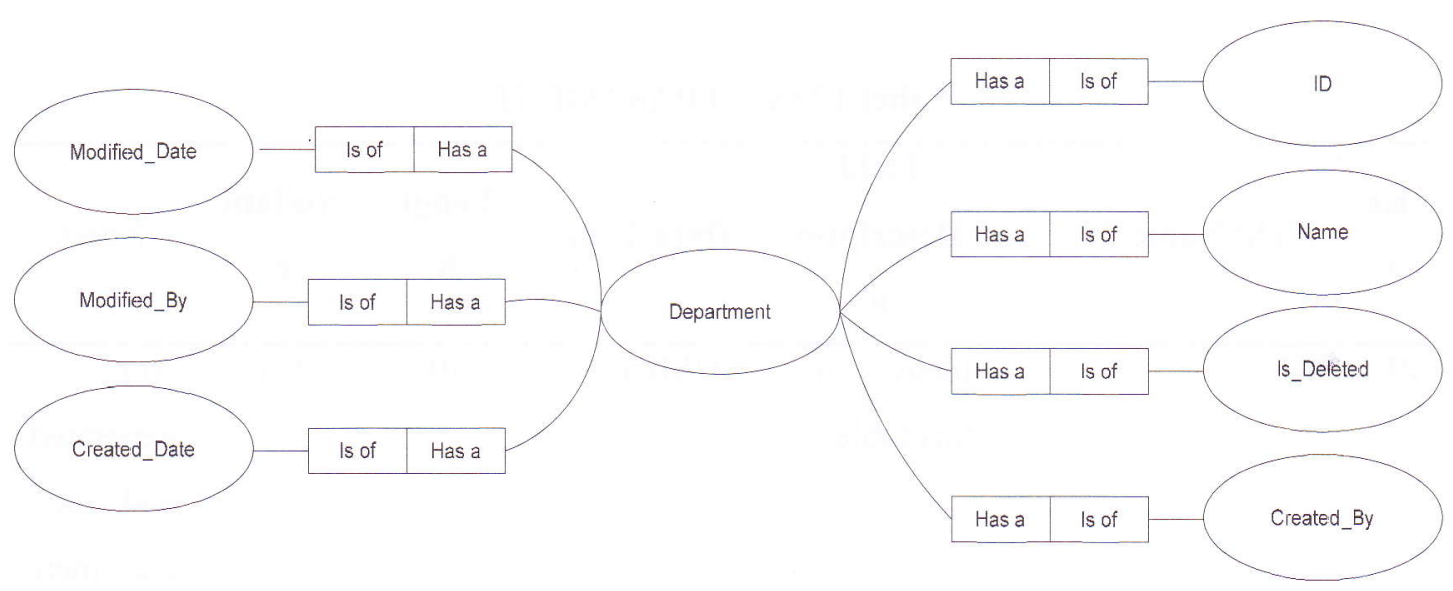

Gambar 11 Diagram ORM Master Department

Gambar 11, menunjukkan diagram ORM dari Master Department yang memiliki atributatribut yaitu $i d$, name, is_deleted, created_by, modified_date, modified_by, created_date. 
Mapping atribut-atribut tersebut, dibuat dari dari suatu berkas $x m l$ yang kemudian akan disimpan pada tabel dalam basis data.

\subsection{Implementasi Konsep MVP dan ORM}

Sistem ini dikembangkan dengan menggunakan teknik Model View Presenter (MVP), aturan bisnis berjalan sesuai kondisi yang ditentukan oleh pihak perusahaan. Untuk implementasi MVP dan ORM diambil contoh pada modul Master Management dimana telah terdapat aturan bisnis sesuai analisis kebutuhan.

Pada MVP, view menunjukkan representasi yang akan ditunjukkan/ditampilkan kepada pengguna, model sebagai definisi struktur object, repository menyediakan pemodelan data, menerima masukan dan fungsi-fungsi lainnya untuk pengaturan akses pada basis data, dan pada presenter terdiri dari logika untuk melakukan kontrol terhadap view dan model. Untuk melihat komponen secara lengkap yang digunakan dalam implementasi MVP, dapat dilihat pada Gambar 13.

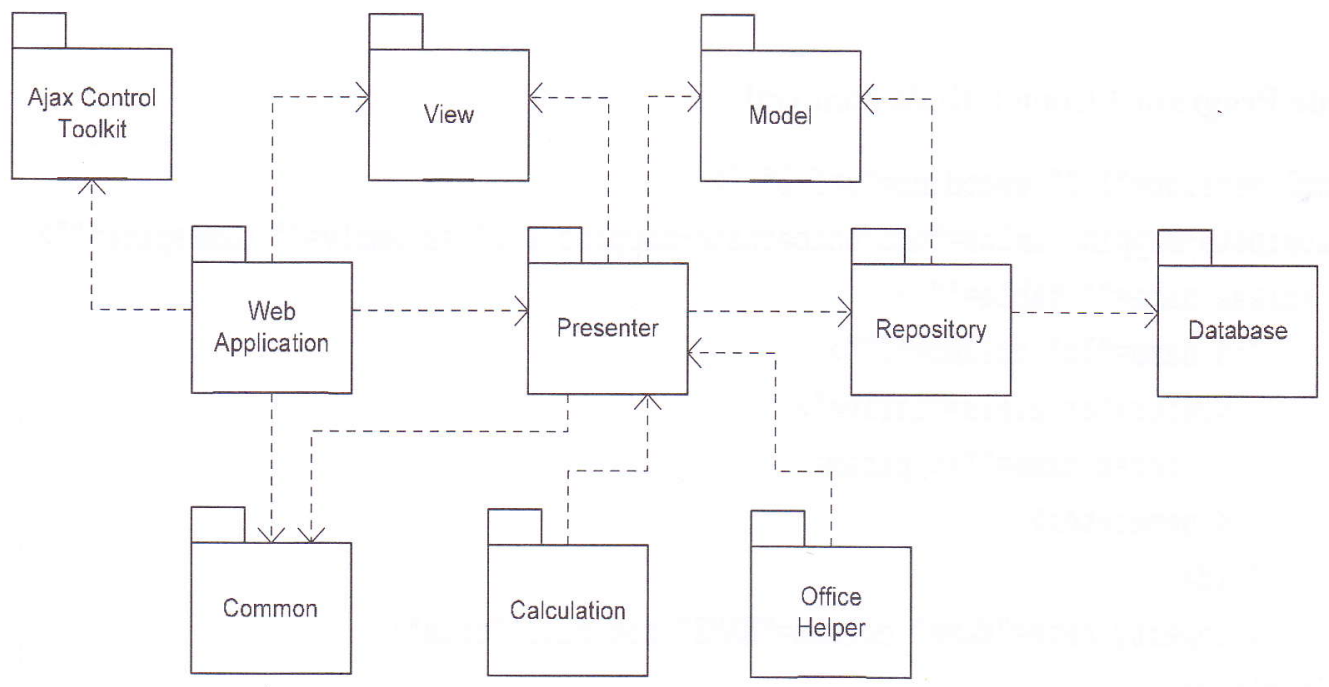

Gambar 12 Ilustrasi Komponen dalam Arsitektur Aplikasi

Gambar 12 memperlihatkan ilustrasi hubungan antar komponen. Web Application merupakan Graphical User Interface (GUI) yang dibuat untuk tampilan ke pengguna, View merupakan class yang menampung nilai dan untuk menghubungkan GUI dengan Presenter. Presenter merupakan bagian yang digunakan untuk memasukkan business logic, perpindahan data dari View ke Model atau sebaliknya. Model merupakan class yang digunakan untuk menampung data dari Presenter dan Repository. Repository merupakan bagian yang digunakan untuk logical process basis data dalam melakukan tambah, lihat, ubah, dan hapus data. Database merupakan tempat penyimpanan data. Ajax Control Toolkit merupakan class yang digunakan untuk operasi AJAX pada GUI. Common merupakan 
class yang umum dipakai sebagai penunjang dalam membuat aplikasi. Office Helper merupakan class yang dibuat untuk Interop (cara mengakses Excel). Selain itu, implementasi konsep terhadap penggunaan ORM ketika ada definisi data berupa person yang memiliki atribut $i d$ dan name. Tanpa menggunakan ORM, untuk menyimpan obyek tersebut ke dalam basis data dengan menjalankan perintah SQL:

INSERT INTO Person (id, name) VALUES ('1', 'Ando');

Dengan menggunakan ORM, perintah tersebut akan digantikan dengan fungsi misalkan save() (bergantung pada library ORM yang disediakan), sehingga pemanggilnya adalah:

$$
\begin{aligned}
& \text { Person prs = new Person (' } 1 \text { ', 'Ando'); } \\
& \text { prs.insert(); }
\end{aligned}
$$

ORM yang akan memetakan fungsi insert() sama halnya dengan perintah SQL "INSERT". Library yang akan digunakan adalah NHibernate pada .NET platform. Pemetaan entitas ke dalam tabel menggunakan ORM NHibernate juga dibantu dengan berkas $x m l$ yang berfungsi untuk pemetaan atribut-atribut dari obyek tersebut ke dalam basis data. Contoh penggunaan hbm.xml terlihat pada Kode Program 1.

Kode Program 1 Contoh Kode hbm.xml

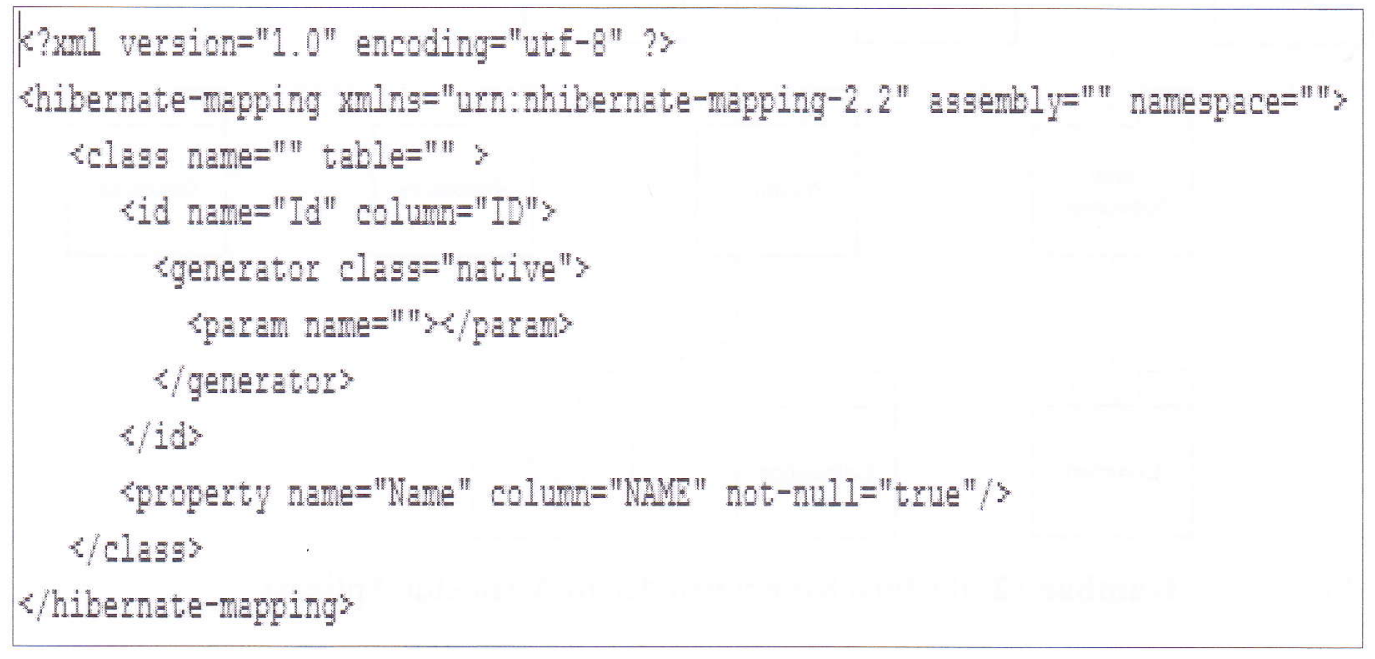

\section{IMPLEMENTASI DAN ANALISIS HASIL}

\section{Hasil dan Pembahasan Implementasi Model View Presenter dan Object Relational Mapping}

Saat ini konsep MVP sudah diimplementasikan ke dalam sistem. Secara fisik program, komponen-komponen yang digunakan, terlihat pada Gambar 13. 


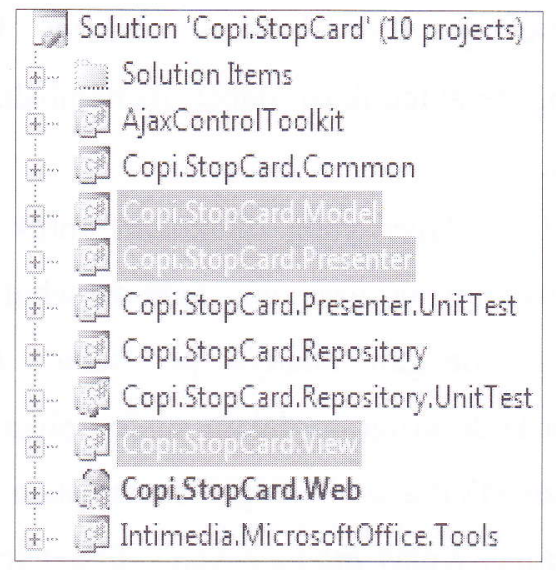

Gambar 13 Paket Komponen Implementasi MVP

Bagian-bagian dari implementasi Model View Presenter itu dipisahkan ke dalam paket-paket yang berbeda yaitu Model, View, dan Presenter, agar dapat terlihat dengan jelas dimana posisi serta tugas dari masing-masing komponen tersebut. Pemisahan dari masingmasing komponen tersebut dimaksudkan agar pengerjaan aplikasi dibagi-bagi ke dalam beberapa komponen/bagian sehingga kedepan memudahkan pengembang aplikasi dalam melakukan maintain. Selain itu ada juga penambahan komponen yang dapat menunjang kinerja dari MVP yaitu AjaxControlToolkit, Common, Presenter.UnitTest, Repository, Repository.UnitTest, Web, dan OfficeHelper. Dalam aplikasi ini, untuk pengaturan login pengguna ditentukan berdasarkan pengguna yang terautentikasi oleh service dari perusahaan dalam arti hanya pengguna yang tercatat dalam basis data yang bisa masuk dan menggunakan aplikasi ini. Kode Program 2 merupakan perintah yang berfungsi mengatur service autentikasi pengguna ke sistem utama perusahaan.

Kode Program 2 Autentikasi Pengguna dalam System Admin

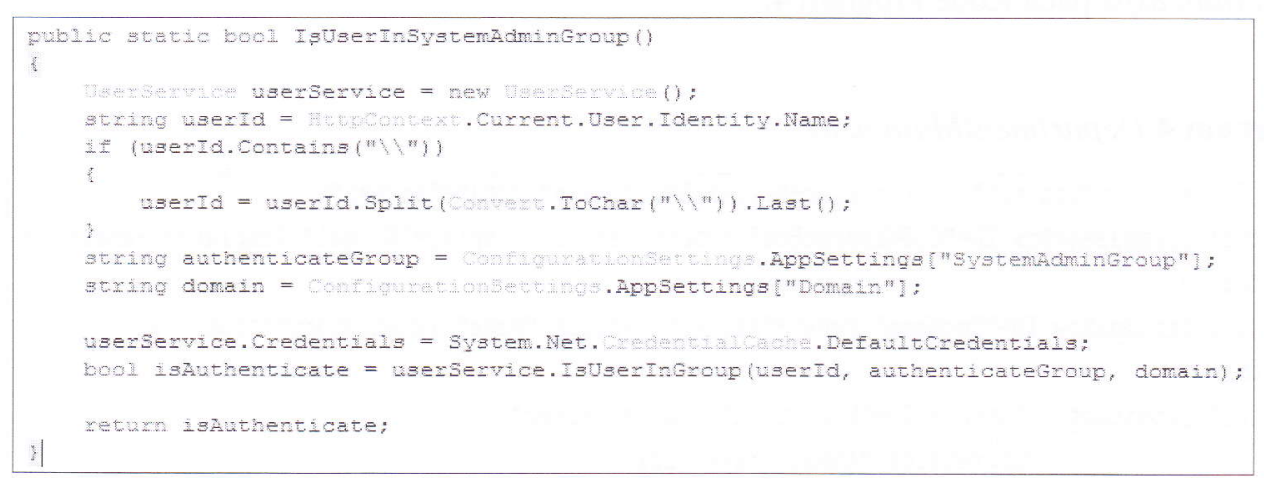

Dalam tahap pengembangan aplikasi, untuk tiap kali running diasumsikan pengguna telah login dengan menetapkan nilai true pada kontrol login, seperti kode program COPSiteNavigationHeader1.EnableLoginStatus=true; agar tidak perlu dilakukan login 
pengguna secara berulang-ulang. Pada halaman Master Management yaitu modul Department, pengguna yang terautentikasi dapat menambah, melihat, mengubah, dan menghapus data Department.

Terdapat pemisahan logic layer yang dilakukan untuk mengatur bagaimana user interface berperilaku dan bagaimana user interface tersebut berinteraksi dengan core application. Selain itu juga dengan adanya pemisahan layer dapat memudahkan programmer dalam merawat kode program dalam suatu aplikasi. Langkah awal membuat aplikasi dengan menggunakan MVP adalah dengan menuliskan test class, dimana test class ini adalah suatu kelas interface. Kelas inteface yang dibuat merupakan persyaratan awal untuk suatu kode dapat dilakukan compile dengan benar. Misalnya dalam kasus ini bagaimana menuliskan test class dalam melakukan implementasi MVP pada submodul Department. Kode Program 3 merupakan kelas interface dari IMasterDepartmentView.

Kode Program 3 IMasterDepartmentView

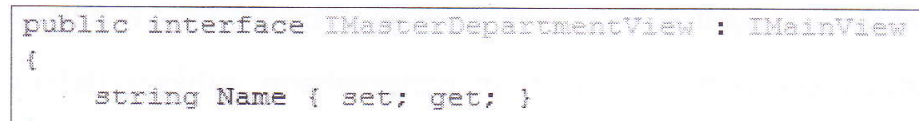

Implementasi Interface IMasterDepartmentView pada Kode Program 3 merupakan turunan dari IMainView, dengan pemberian dan pengembalian suatu nilai dari variabel Name. Dengan melakukan implement pada IMasterDepartmentView, maka pada web page memiliki suatu tanggung jawab untuk implement suatu method atau properties yang telah didefinisikan dalam interface tersebut. Terdapat dua properties pada interface IMasterDepartmentView dan itu adalah set dan get, yang dapat memberikan dan mengembalikan suatu implementasi dari variabel string Name. Selanjutnya perlu dibuat ASPX untuk halaman Master Department, yaitu DepartmentMain.aspx pada Kode Program 4.

\section{Kode Program 4 DepartmentMain.aspx}

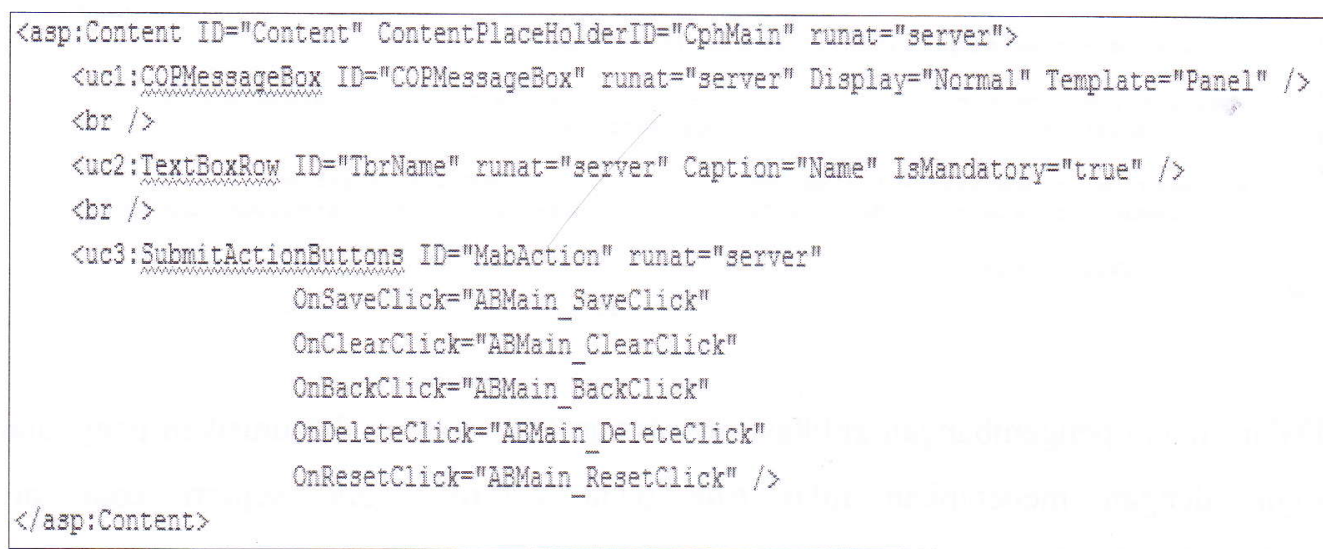


Berikutnya perlu dibuat MasterDepartmentPresenter, dimana pada kelas ini terdapat beberapa hal penting yaitu constructor, method, dan validation. Instansiasi aktual dari suatu presenter merupakan tempat yang menggantikan code behind untuk web page. Walaupun demikian hal ini bisa menjadi masalah jika tidak ada suatu reference kepada service layer. Untuk menyelesaikan masalah tersebut, perlu ditambahkan suatu overloaded method pada kelas MasterDepartmentPresenter dengan perintah pada Kode Program 5.

Kode Program 5 Overloaded Method MasterDepartmentPresenter

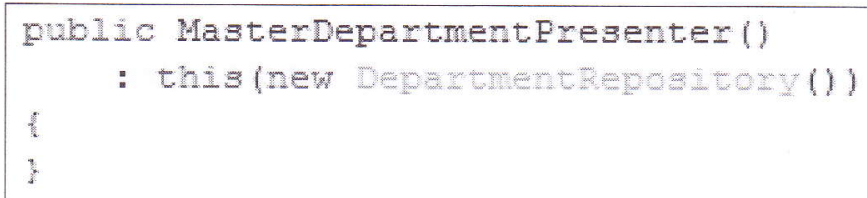

Pada konstruktor kelas MasterDepartmentPresenter dibuat suatu obyek dari kelas DepartmentRepository, yang digunakan untuk menerima input parameter dari kelas MasterDepartmentView, sehingga pada konstruktor tersebut ditambahkan method, yang nantinya akan terdapat implement untuk DepartmentRepository secara lengkap, terlihat pada Kode Program 6.

Kode Program 6 Constructor pada Presenter

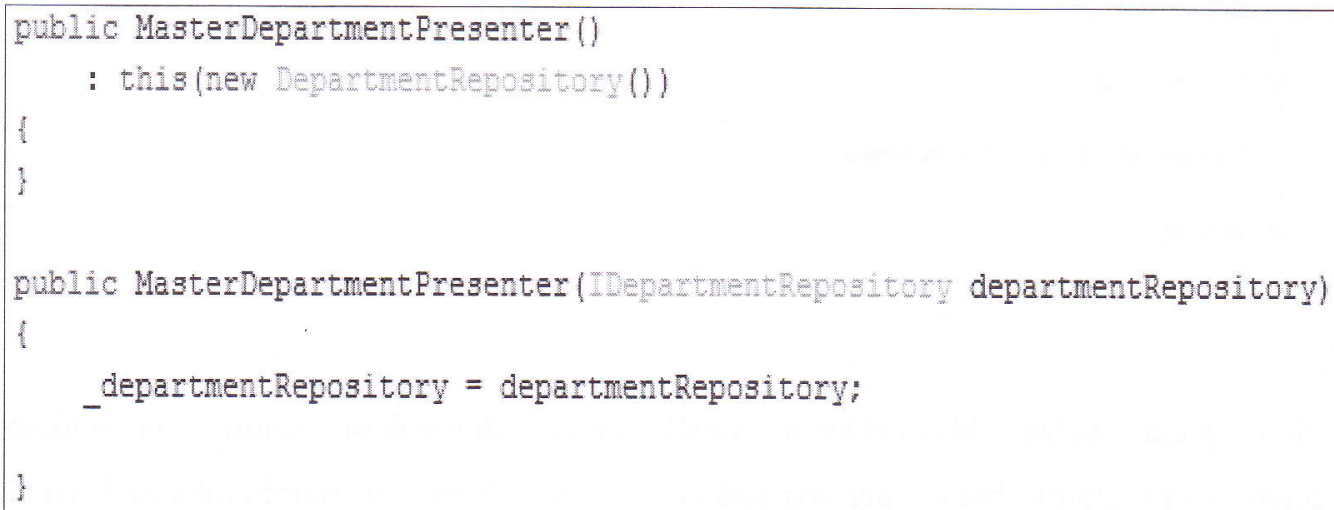

Selain itu juga, dalam kelas presenter ini terdapat method yang digunakan sebagai service implementation, misalnya salah satu method OnSave() yang digunakan untuk menyimpan data ke basis data, dengan perintah pada Kode Program 7. 
Kode Program 7 Fungsi OnSave()Pada Kelas Presenter

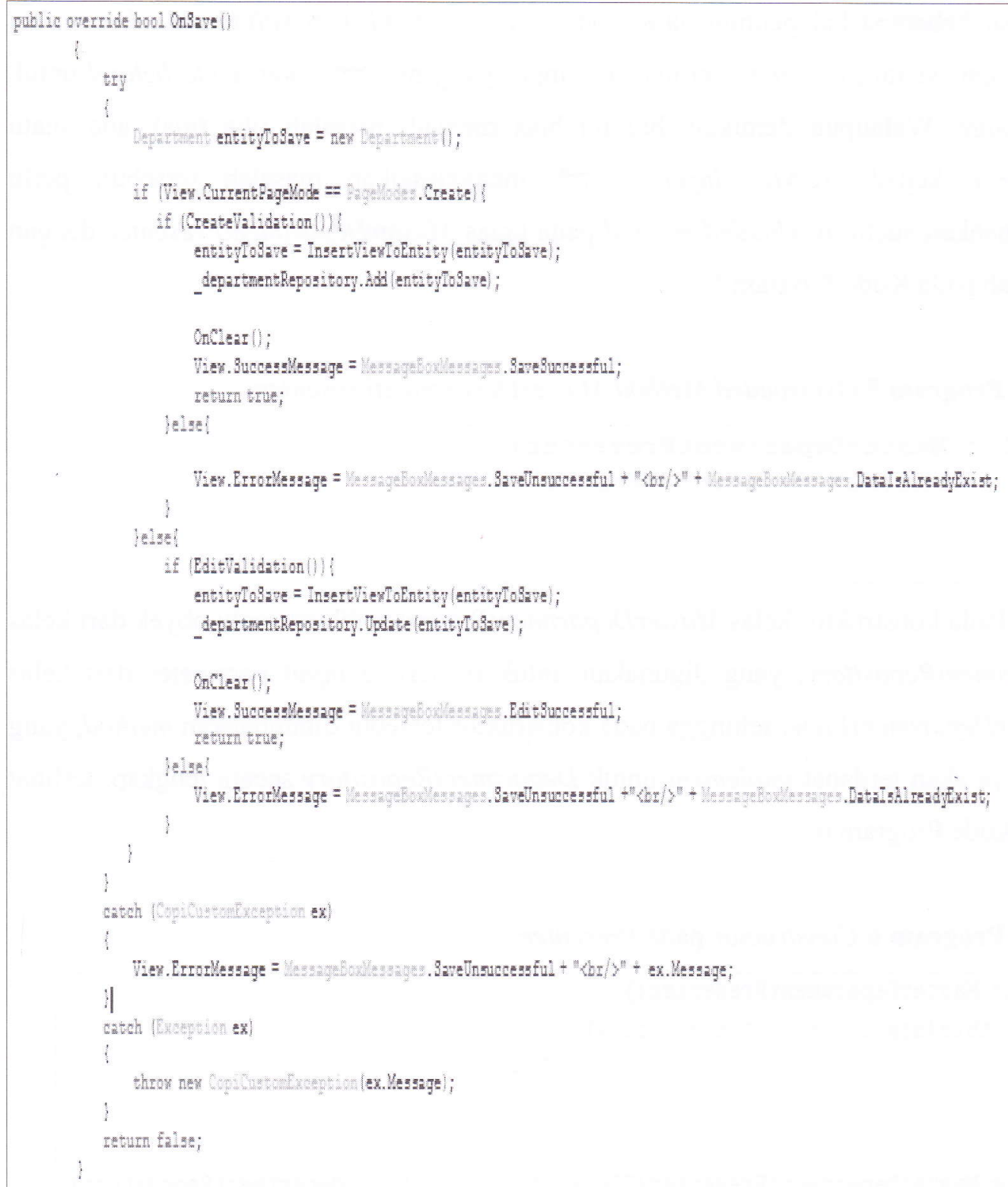

Validation pada kelas MasterDepartmentPresenter digunakan untuk melakukan pengecekan data melalui obyek yang ada pada repository. Presenter membutuhkan 3 (tiga) hal tersebut (constructor, method, validation) dalam kerangka performa kerja dari presenter itu sendiri.

Komponen model digunakan sebagai definisi struktur obyek dengan mendefinisikan atribut-atribut dari obyek tersebut dan yang akan dipetakan ke dalam tabel pada basis data, dengan menggunakan pendekatan hbm.xml dan kelas yang dibuat (Kode Program 9) untuk melakukan mapping object ke xml. 
Kode Program 8 Class Department untuk Mapping Object ke hbm.xml

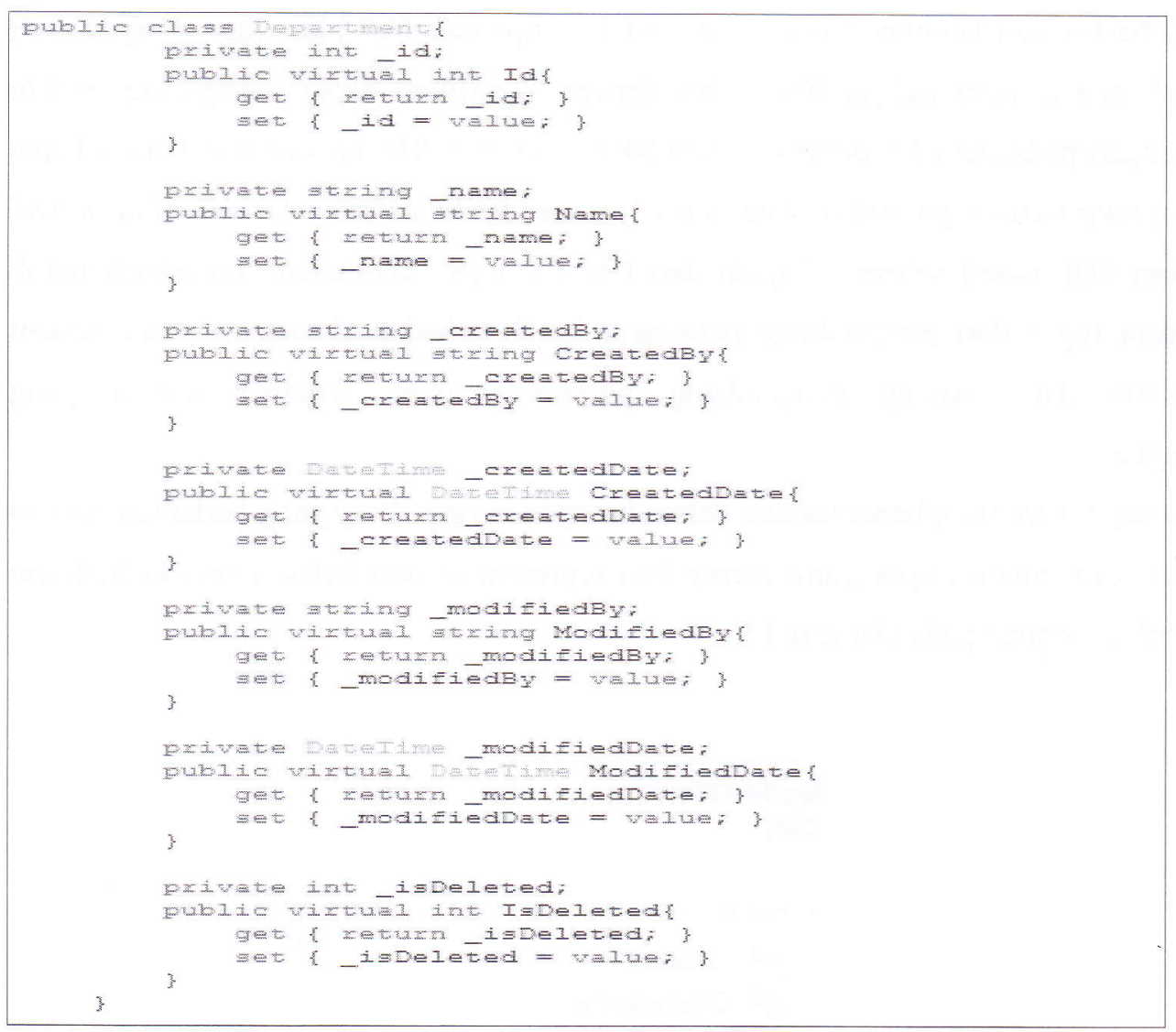

Setelah ada kelas yang tersedia pada Kode Program 8, selanjutnya diterapkan suatu Object Relational Mapping (ORM) dengan NHibernate menggunakan hbm.xml, ditunjukkan pada Kode Program 9.

Kode Program 9 ORM Nhibernate-Mapping ke Tabel MS_DEPARTMENT

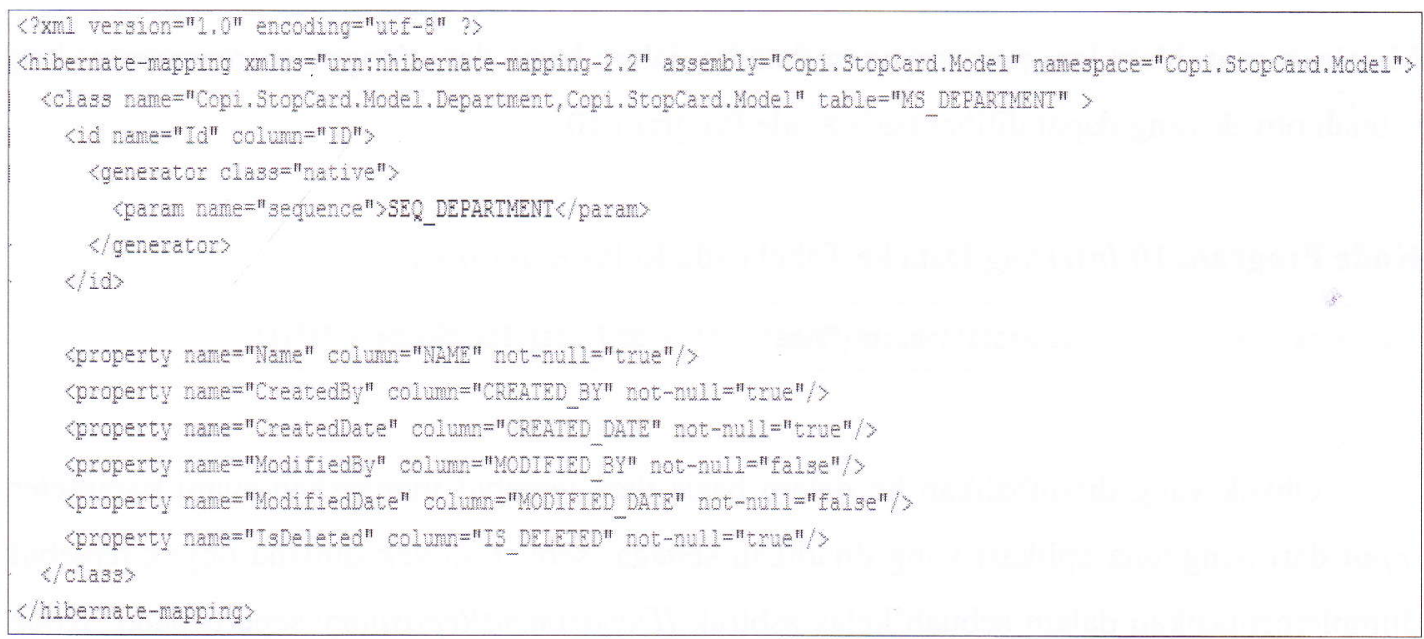


Penggunaan NHibernate tidak hanya melakukan mapping dari kelas-kelas pada .NET ke tabel pada basis data (dan juga dari tipe data. NET ke tipe data SQL) tapi juga menyediakan suatu data query, retrieval facilities, dan dengan signifikan dapat mengurangi waktu pengembangan pada data handling di ADO.NET. Aturan ORM ini dimaksudkan sebagai teknik mapping suatu representasi data dari object model ke dalam relational data model berdasarkan SQL-based schema. Tujuan dari ORM dengan NHibernate ini adalah untuk meringankan tugas dari pengembang perangkat lunak terhadap data persistence terkait tugas utama dari seorang pengembang perangkat lunak terhadap sistem yang dikembangkan.

Konsep ORM diimplementasikan dalam komponen repository yang berkaitan dengan pendekatan xml. Suatu obyek yang merupakan representasi dari kelas memiliki berbagai macam atribut, terlihat pada Gambar 17.

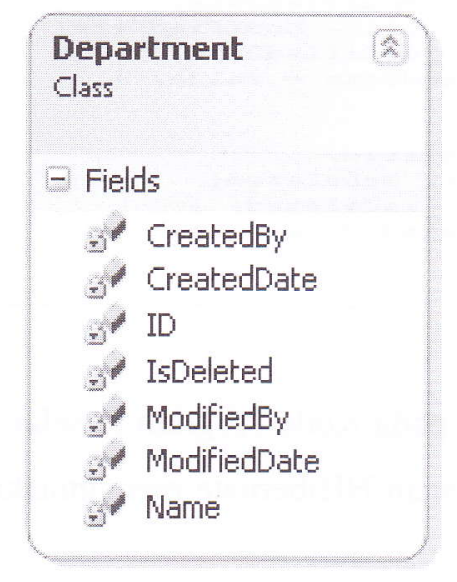

Gambar 14 Object Department

Misalnya saat dilakukan penyimpanan data ke dalam basis data dengan merepresentasikan sebuah obyek yang dapat dilihat pada Kode Program 10.

Kode Program 10 Inserting Data ke Tabel pada Kelas Repository

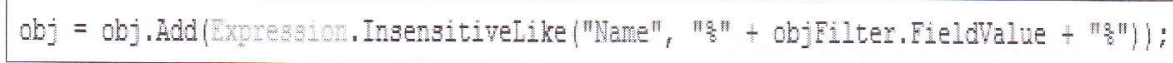

Obyek yang ditambahkan ke dalam basis data tersebut merupakan suatu parameter input dari pengguna aplikasi yang dijadikan sebagai sebuah obyek dimana obyek tersebut diimplementasikan dalam sebuah kelas asbtrak IDepartmentRepository seperti pada Kode Program 11. 
Kode Program 11 Kelas abstract untuk IDepartmentRepository

public abstract Depantment RetrieveByName (string name):

Pada dasarnya, melakukan pemetaan suatu obyek ke dalam basis data sama halnya dengan melakukan pemetaan suatu collection dengan menentukan key dan value.

Dalam melakukan penyesuaian terhadap unit testing, MVP mendukung adanya unit testing. Kode Program 12, menunjukkan unit test yang diletakkan pada komponen presenter.

Kode Program 12 Script Test untuk Unit Test pada MasterDepartmentPresenterTest.cs

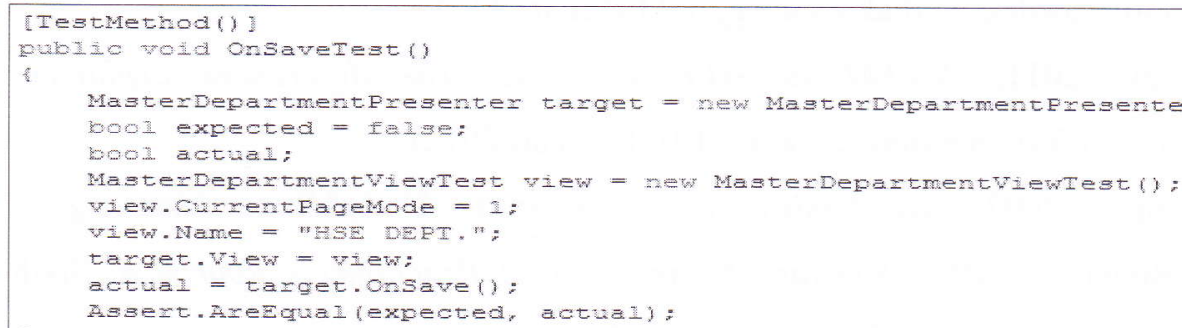

Melakukan unit testing pada teknik MVP dapat dilakukan pada komponen presenter karena seluruh logika bisnis diletakkan pada komponen tersebut, selain itu presenter adalah sebagai penengah antara view dan model. Sehingga cukup dengan menguji kelas-kelas atau fungsi-fungsi yang ada dalam presenter maka dapat diketahui apakah proses yang ada sudah sesuai dengan aturan atau belum.

\section{KESIMPULAN}

Implementasi Model View Presenter (MVP) dan Object Relational Mapping (ORM) menghasilkan suatu aplikasi web yang terstruktur dan mudah untuk dilakukan pemeliharaan, karena pengerjaan aplikasi dibagi-bagi ke dalam beberapa komponen/bagian dengan pemisahan layer yang jelas. Selain itu juga, efektif dalam melakukan unit test, karena hal ini dapat dilakukan cukup dengan meletakkan suatu script test pada komponen presenter. 


\section{Daftar Pustaka}

[1] McCafferty, Billy., 2007., Model View Presenter with ASP.NET., (http://www.codeproject.com diakses tanggal 7 Februari 2012)

[2] PAU, Valentin Corneliu, et al., 2010., Model View Presenter Design Pattern., (http://search.ebscohost.com diakses tanggal 7 Februari 2012)

[3] Saltarello, Andreaa., \& Esposito, Dino., 2009., Microsoft .NET: Architecting Application for the Enterprise (PRO-Developer).

[4] Kuaté, Pierre Henri., et al., 2008., NHibernate in Action., Manning Publications.

[5] Microsoft Team, 2012., Model-View-Presenter Pattern, Microsoft Library. (http://msdn.microsoft.com diakses tanggal 7 Februari 2012)

[6] Wenzel, Joel., 2011., MVVM vs MVP vs MVC: The differences explained. (http://joel.inpointform.net diakses tanggal 10 Februari 2012)

[7] Bauer C, King G., 2007., Java Persistence with Hibernate., United States: Manning.

[8] Pressman, Roger S., 2005., Software Engineering: A Practioner's Approach. Sixth Edition., New York: McGraw-Hill Companies, Inc. 